\title{
SYSTEM-FORMING INNOVATIVE INSTITUTIONS OF THE AGRARIAN MARKET
}

\author{
Maksym Odnorog ${ }^{1}$, Nataliia Kraus ${ }^{2}$, Liudmyla Savchuk ${ }^{3}$
}

\begin{abstract}
The agrarian market of Ukraine and its basic component, agriculture, is the backbone of the national economy, forms the basis of preserving the sovereignty of the state food and, within a certain range, economic, environmental, and energy security, ensures the development of technologically related sectors of the national economy, and forms socio-economic development of rural areas, therefore, the purpose of the paper is to develop scientifically-based proposals to identify the role of strategic institutions of the agricultural market. Methodology. The theoretical and methodological basis of the research is the dialectical method of cognition and systematic approach, which are used for studying theoretical and methodological foundations of strategic innovation institutes of the agricultural market. The results showed that the article examines the strategic factors that determine the efficiency of functioning of the agrarian market. The results of the monitoring and analysis of the formation of the institutional market environment are presented. There are proposed a model and priority directions of formation and development of systematizing institutions of the agricultural market. Practical implications. The studied institutions create incentives for the development of science and education, encourage the mobility of production factors, facilitate the transfer of scientific and technical information and the introduction of new technologies, promoting entrepreneurship and innovation. Conversely, inefficient institutions reduce the potential level of wellbeing, reliability of property rights, and enforcement of contracts. Value/originality. The increasing importance of innovation institutions of the agricultural market enables you to define the latter as an important intangible factor in the development of the economy and society that create the conditions necessary for the transformation and development of the agrarian market. The system of formation of a modern institutional environment should include a system of regulators, which would provide favourable conditions for attracting domestic and foreign investment, further structuring of the economic complex of the agricultural market, reduction of regional asymmetries of socioeconomic development. How full individual investment units will operate in the institutional environment depends on the realization of economic and social development priorities of the Ukrainian village.
\end{abstract}

Key words: institute, institute of agrarian market, model and directions of formation of market institutions.

JEL Classification: O31, O32, E11, G20, G23, N20, 017, P32, F14, N50, O13, Q12

\section{Introduction}

The genesis of a new institutional theory in a significant way changes the view of the understanding of the role of the institutional environment in shaping and improving the food security of the country. In this sense, it is impossible to do without a formalization of the influence of the institutional environment, without measuring the magnitude and direction of this influence. Among the main elements of the institutional environment of socio-economic development of the agrarian market are: state property (land and means of production), labour, competition, infrastructure, and price. They stimulate production, increase the investment attractiveness of the agricultural sector, lead to an improvement in the financial condition of producers, and improve the availability, quality, and safety of food products. The research methodology of the influence of the institutional environment of the agrarian market

\footnotetext{
Corresponding author:

${ }^{1}$ Scientific-Research Financial Institute,

State Educational-Scientific Establishment “Academy of Financial Management”, Ukraine.

E-mail: odnorog_btnau@ukr.net

ORCID: https://orcid.org/0000-0002-6650-6181

${ }^{2}$ Borys Grinchenko Kyiv University, Ukraine.

E-mail: k2205n@ukr.net

ORCID: https://orcid.org/0000-0001-8610-3980

${ }^{3}$ Bila Tserkva National Agrarian University, Ukraine.

E-mail: savchukliudmylaO@gmail.com

ORCID: https://orcid.org/0000-0002-5061-8605
} 
should be created through the identification of linkages between institutions characterized by a degree of influence of elements of the institutional environment.

One of the most important strategic factors determining the efficient functioning of the agricultural market is development and availability of a number of market institutions. For the successful development of the agrarian economy of the country, region, and individual enterprises, the modern state and public monitoring of formation and development of institutions require analysis with the purpose of revealing discrepancy of technical, technological, and economic factors existing in the institutional environment of the agricultural market, leading to increased uncertainty and risk of business behaviour. This, in turn, is a major factor in increasing transaction costs, which require changes in existing institutions.

The processes associated with the further institutional restructuring of the national system of agrarian business take another one place in the area of the development of an effective set of social and economic formations, or formal institutions of the content market. Entrepreneurship is a fundamental institution that serves as a factor of the functioning of the agrarian economy. Publishing of scientific publications on the problems of agricultural enterprises is predominantly a classical implication, therefore, institutional studies of areas of interest.

One of the problems of effective development of agrarian business is the need for the development of the value chain that allows you to efficiently develop and operate small and medium-sized producers. The agrarian market institute provides such a development in terms of vertical and horizontal integration of producers, in the process of their joint activities. The problem is obvious; therefore, it is appropriate and adequate to assess the development of the agrarian market and its institutions from both theoretical and practical points of view.

The process of formation and development of formal and informal market institutions continues, both in the process of improving the mechanisms of state regulation of the agrarian market and in the process of increasing its effectiveness. A better understanding of market processes and factors of effectiveness of agricultural market is of practical importance for adequate market regulation.

Analysis of recent researches and publications shows that the issues related to the formation and development of the agrarian market and its institutions were viewed by domestic and foreign economists. Works of many domestic scientists are devoted to the theoretical fundamentals and improvement of the categorical-conceptual framework of the agrarian market: (Andrijchuk, 2013), (Gajduckyj, 2004), (Sabluk, 2010). At different times, such scientists as (Grycenko, 2008), (Zagurskyj, 2014), (Lopatynskyj, 2006), and others investigated in their writings problems of the agricultural market through the prism of the theory of institutionalism, institutions, and institutes. However, the analysis of the studied categories leads to the conclusion that not all aspects of institutional development of the agrarian market are considered, and especially in the issue of forming institutions.

The goal of the article is to develop evidence-based proposals and identify the role of strategic institutions of the agricultural market.

The theoretical and methodological basis of the research is the dialectical method of cognition and systematic approach, through which theoretical and methodological foundations of an innovative component of institutions of the agricultural market are considered.

\section{Strategic determinants of the efficiency of functioning of the agrarian market}

Society and state are a complicated organizational system. The system is an organized structure consisting of elements (subsystems) connected by links and the total objective function, which is controlled by the "core" of the system, its subsystems, and the control connection in order to maintain the system, to transform or destroy it.

For the effective and coordinated functioning of the system, one should adhere to certain requirements:

- continuous identification of target priorities;

- maintaining and strengthening purposes and functions of the system;

- the removal of internal contradictions, as in the system kernel and between the kernel and subsystems (Grycenko, 2008);

- levelling of system fluctuations in order to avoid going beyond sustainability.

The crisis in the agrarian economy of our country in the 90s, according to some scientists (Gajduckyj, 2004), is largely systemic in nature. This means that during the operation of the agrarian economy as a complex multilevel socio-economic system, the so-called systemforming factors have been lost, without which the system dramatically reduces the effectiveness of governing relations, which in turn leads to a weakening of the objective function of all the elements of its components.

One of the most important system-forming factors determining the efficient functioning of the agricultural market is underdevelopment and the absence of a number of its market institutions. For the successful development of the agrarian economy of the country, region, and individual enterprises, analysis of the modern state is required, as well as public monitoring of formation and development of institutions of the agricultural market in order to detect inconsistencies in technical, technological, and economic factors existing in the institutional environment of the agricultural market, which results in increased risk and uncertain 
business behaviour. This, in turn, is a major factor in increasing transaction costs, which require changes in existing institutions.

The purpose of continuous monitoring and analysis of the formation of the institutional market environment is also to identify the priority areas of its formation and development. A model of systematizing market institutions is developed and presented in Figure 1.

Agricultural Economics is a part of the country's economy and it fully reflects its problems. However, it has, in our opinion, a number of specific system-forming institutions in the agrofood market, which are related with a feature of economic relations and arise from the peculiarities of the central sphere of the agro-industrial complex, which as a branch is agriculture. Such specific institutions that require priority in the formation and development and the effectiveness of which largely determines the efficient functioning of the agricultural market as a system are:

- underdeveloped institutions of land tenure and land use (Sabluk, 2010);

- lack of efficient owner institution and, as a consequence, the inefficient functioning of market legal forms;

- underdevelopment and inefficiency of institutions of state regulation and state support, which, in turn, includes sales guarantees and sustainable minimal profitability of agricultural producers in a changing market environment.

\section{Priority directions of formation and development of major systemically important institutions}

Priority directions of formation and development of key systemically important institutions of the agricultural market are presented in Figure 2.
Production structures are one of the most conservative elements of socio-economic systems. Their change and improvement require a significant investment of time.

Radical institutional changes occur more slowly. Especially conservative informal institutions are associated with the change of people's consciousness. However, they create a legitimate basis for the laws. Such drastic (revolutionary) changes, carried out not from below (objective) and imposed from above, often lead to negative results in economic transformations (Zagurskyj, 2014).

In the former socio-economic system, the effect of such a powerful group of motivations was eliminated as the motivation of having the right of ownership, whereas in the market organizational and economic mechanisms, it occupies one of the leading places.

To achieve the success of the agrarian reform and ensure the long-term and sustainable economic growth, first of all, modification of informal norms of behaviour that legitimate new laws and regulations which are the basis for the formation of new motivation mechanisms in society is necessary (Andrijchuk, 2013).

The most effective, as experience shows, are flexible institutional structures, able to adapt to new conditions in a wide range.

An objective assessment of institutional losses, acquired during the existence of the administrativecommand system, allows you to note the number of benefits associated primarily with the achievement by the country's population of high-level general and special education, as well as access to the advanced technological frontier in several industries. We made an attempt to assess, generalize, and systematize institutional advantages and losses incurred over the years of the command economy (Table 1).

Failure to comply with technical, organizational, and technological factors existing in the institutional

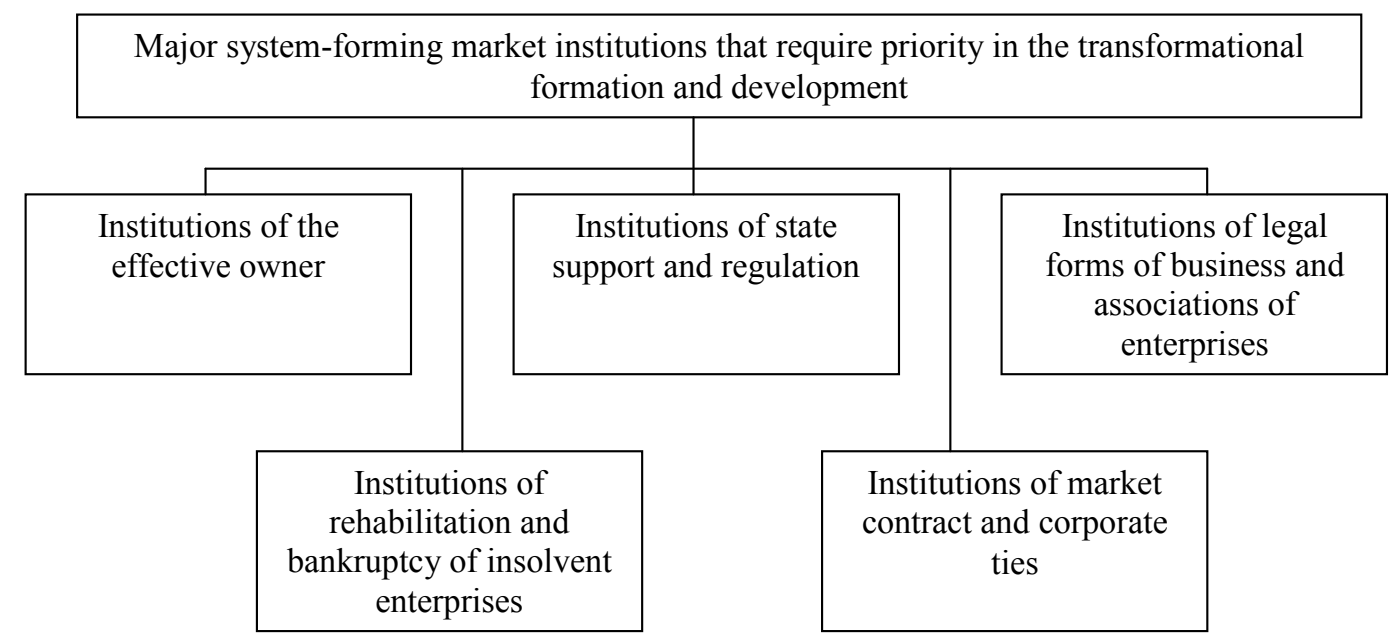

Figure 1. Major systemically important market institutions in most urgent need of transformational formation and development

Source: developed by the author 


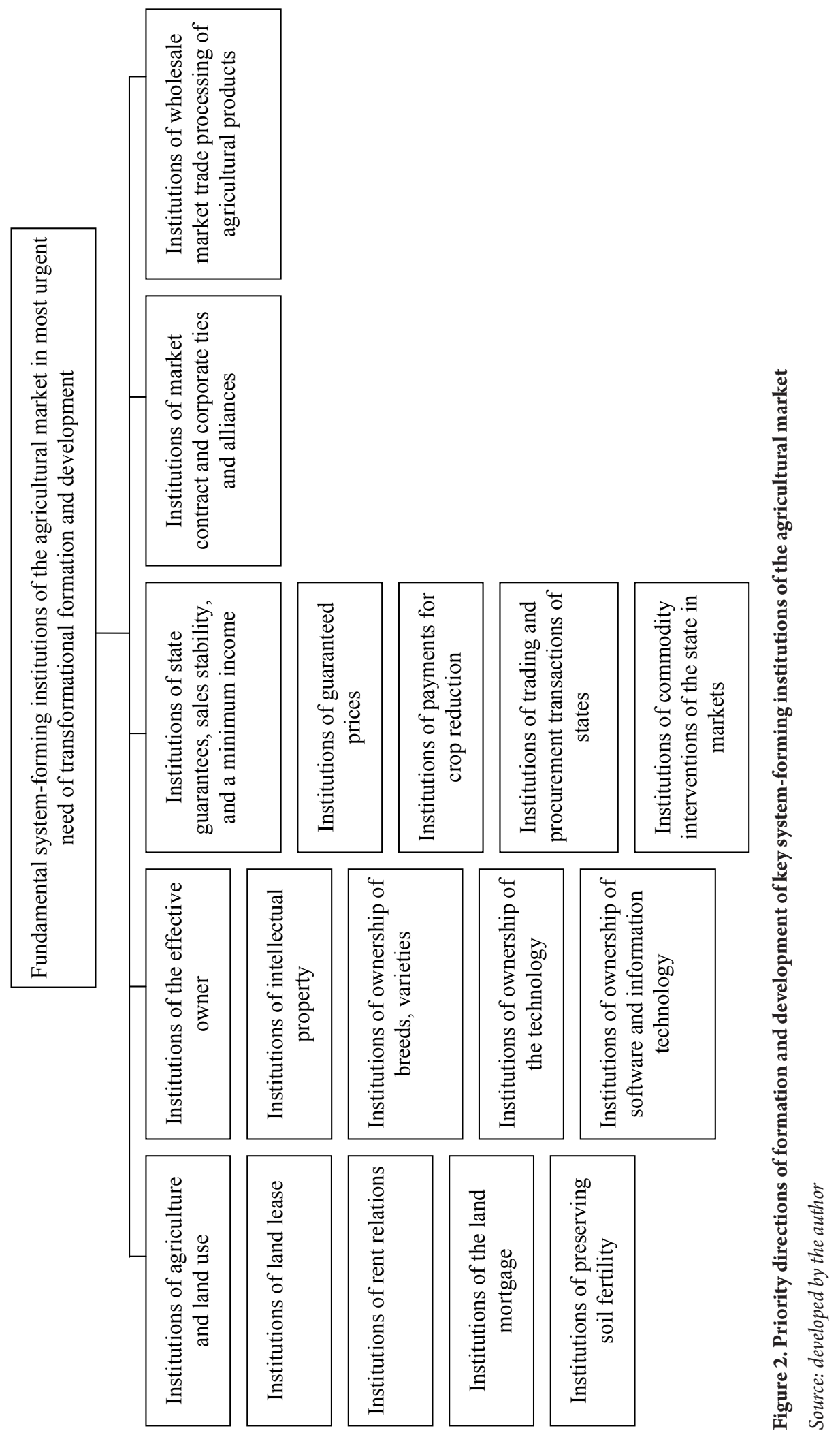


environment of the agricultural market leads to uncertainty of entrepreneurs who, in turn, are a factor of increase in costs of transaction operations. Inadequate organization and lack of a culture of contractual relations and other informal institutions lead to an increased risk in commerce and entrepreneurship.

Thus, the solution to the problem of institutional change in the agricultural sector implies creating a multilevel structure and an infrastructure of the agrarian market, which will allow forming an effective owner and implementing more fully the action of market mechanisms and institutions (Lopatynskyj, 2006).

The concept of institutionalism in a market economy is an interpretation of the theory of social relations in a society represented as a structure consisting of influencing each other groups, the hierarchy of relationships among them, mediated by social institutions. Social connections are considered to be organized, controlled, and managed.

\section{Informal institutions in the system of institutional relations}

The greatest difficulty in the system of institutional links is represented by informal institutions, that is, unwritten rules, and professional codes of conduct. Along with the formalized, they exist as an inner voice, the imperative of practical and not just theoreticallyoriented social behaviour that is taking place in the direction: "it is developed not by us and it is not ours to refuse." Often informal institutionalization is supported or weakened in the process of social communication. In all types of partnership, it is not only intrinsically valuable but predetermines a lot.

Considering the current status of major institutions in the agricultural market, as well as their role in the effective functioning of market mechanisms and instruments necessitated the recourse to the epistemological roots of traditions and customs that underlie the national mentality of the peoples of Ukraine.

The mentality is largely determined by nature and climate where these people live and the conditions of agricultural labour and prevailing economic patterns: nature often laughs at the most careful calculations: the perversity of climate and soil deceives modest expectations.

The main feature of the mentality is the habit to work for a short time, excessively hard and fast.

Features of traditions and customs in the behaviour of people living in Ukraine are determined by the centuries of the existence of the Ukrainian peasant in the framework of such a form of social organization as a rural community. Community, originating in prefeudal time, was the organization that united the collective and private origins in the land tenure system.

The Ukrainian peasant community had a number of development features, which were stabilization and strengthening of community institutions and wide use of equitable redistribution of land among its members in the seventeenth and eighteenth centuries. The community carried out a number of functions of social protection and social security of its members. As noted by some researchers, the development of capitalism in the agriculture of Ukraine did not manage to destroy peasant communities; they existed even in the end of the XIX - the beginning of the XX century.

All these institutional features, in our opinion, should be considered when forming market institutions, both at the macro and micro level.

Within the theory of $\mathrm{R}$. Coase, there are allocated institutions that define general rules of the game at the macro level, which include: the legal system; contract

Table 1

Institutional benefits and losses acquired during the existence of the command-administrative economy in our country

\begin{tabular}{|c|c|}
\hline Institutional losses of the period of socialism & $\begin{array}{l}\text { Institutional benefits acquired during the operation } \\
\text { of the command-administrative system }\end{array}$ \\
\hline $\begin{array}{l}\text { - loss of traditions and culture of the market contractual and } \\
\text { subcontracting relations in the early years was the cause of the } \\
\text { existence of the market predominance of mainly integration } \\
\text { schemes of interaction between its agents; } \\
\text { - loss of customs and traditions, the implementation of property } \\
\text { rights by citizens, which became the main reason for the present } \\
\text { lack of "effective owner". This, in turn, led to insufficient control } \\
\text { by the owner over the management, which reduces the efficiency } \\
\text { of associated forms of entrepreneurship; } \\
\text { - institutions related to efficient use of land and reproduction of soil } \\
\text { fertility are lost and in need of a revival. The main among them are: } \\
\text { institutions of rent relations, land lease, land mortgage, etc.; } \\
\text { - loss of market institutes and mechanisms of their } \\
\text { implementation, associated with the introduction of innovative } \\
\text { high technologies. }\end{array}$ & $\begin{array}{l}\text { - the total literacy of the population that allowed a number of industries } \\
\text { to reach the forefront in the field of engineering and technology; } \\
\text { - in the framework of the planned economy, a number of organizational } \\
\text { institutions are formed that ensure the efficient conduct of scientific } \\
\text { research and introduction of innovative technologies based on } \\
\text { command-administrative principles. For effective functioning, they } \\
\text { need to be adapted to market conditions; } \\
\text { - the country has formed a multi-level system of training and retraining } \\
\text { in vocational schools, technical schools, and universities. Trained } \\
\text { professionals have become carriers of technological knowledge, and } \\
\text { knowledge were transferred in the majority of cases not by succession } \\
\text { but in the formalized way; } \\
\text { - due to the achieved high level of concentration of production and size } \\
\text { of enterprises, the opportunity to get close to world level has appeared } \\
\text { in some sectors of agriculture. }\end{array}$ \\
\hline
\end{tabular}

Source: formed by the author 
law; the regime of property rights. The institutions that set the rules for the functioning and organization of transaction at the micro level or, in the words of Coase, at the level of institutional structures of production, are alternative organizations, transactions, among which he considers: markets, integrated firms, hybrid contractual arrangements (network organizations).

\section{Findings}

For accelerated socio-economic reforms in the agricultural sector of our country, it is necessary to create adequate to the historical conditions of Ukraine, strategically oriented, vertically integrated, and structurally-organized institutional space with power lines of structural priorities of economic complexes and subcomplexes at the level of countries, regions, and industries.

In domestic economic environment under the influence of this space, there are processes of interactions between actors and the sequence of such interactions leads to a further transformation of the entire system. In addition, this interaction extends to the internal space. Therefore, it is possible to speak about the functioning of a certain aggregate institutional space, which is formed by the superposition of individual spaces of various institutions and functional segments within them. The end result of such interaction is the formation of complex three-dimensional configurations, the study of which allows us to consider different variants for the operation of multilevel economic systems and to make a forecast of their development.

\section{Conclusions}

Based on the above, it is proposed to understand agricultural market as the totality of social relations that arise between market participants on the sale of agricultural products and provision of related support services on the principles of competition, free choice of areas of implementation, as well as state control over the safety and quality of agricultural products.

The development of financial relations in the agricultural market, depending on the presence of a complex of factors related to the production, distribution, and allocation of agricultural products and funds, and the formation of a highly developed agricultural market in Ukraine will be the basis of food security, provision of food and financial wellbeing of the population, which in general will mean stability in the social life of our country. Financial relations between the state and business entities in the agricultural market amid the financial and economic crisis should be based on economic development of fair rules of the game between market players and on the improvement of methods of state support, especially for small business entities in the agricultural market through the mechanisms of taxation, crediting, leasing, social projects and so on.

It is established that the institutes and institutions form the background and create the mechanisms of regulation of socio-economic processes of market behaviour, income, expenditure, prices and the like. Analysis of institutional economics has given us the opportunity to form our own vision of the institute and the institution. Established that market coordination and integration, as efficient market institutes, facilitate mutual ordering of the activities of economic entities, forming a suitable environment of interaction and cooperation, according to which each economic agent operates in the market. Depending on the development, the agrarian market coordination is developing and corresponding shapes and types are formed. For this very reason, institutes and institutions of the agricultural market perform the function of continual regulation of the behaviour of market actors, structures of society, create a favourable and predictable environment for market activities.

For accelerated socio-economic reforms in the agricultural sector of our country, it is necessary to form adequate to the historical conditions of Ukraine, strategically oriented, vertically integrated, and structurally-organized institutional space with power lines of structural priorities of economic complexes and subcomplexes at the level of countries, regions, and industries.

The creation of this institutional space will allow formulating for agricultural entrepreneurs a system of strategic benchmarks, value preconditions, and guarantees, which are indispensable for the ordering of processes of harmonization of economic interests of individual producers in the framework of AIC throughout the technological chain. This, in turn, will reduce business risks and, as a consequence, transaction costs.

\section{References:}

Andrijchuk, V. G. (2013). Agropromyslovi formuvannja novogo typu v konteksti strategii rozvytku vitchyznjanogo silskogo gospodarstva [Agroindustrial formations of a new type in the context of the development strategy of domestic agriculture]. Ekonomika $A P K, 1,3-16$.

Bergman, X. (1969). Razdelenie truda i specializacija v selskom hozjajstve [The division of labour and specialization in agriculture]. (Ju. I. Timofeeva, O. G. Tropova, Trans). Moskva: "Progresc".

Gajduckyj, P. I. (2004). Formuvannja ta rozvytok agrarnogo rynku [The formation and development of agrarian market]. Ekonomika APK, 3, 4-15.

Grycenko, A. A. (2008). Rynkovi instytuty ta infrastruktura [Market institutions and infrastructure]. Ekonomichna teorija, 3, 53-73. 
Jeggertsson, T. (2011). Znanija i teorija institucionalnyh izmenenij [Knowledge and the theory of institutional change]. Voprosy jekonomiki, 7, 4-16.

Zagurskyj, O. M. (2014). Instytucijni chynnyky rozvytku konkurencii na agroprodovolchyh rynkah [Institutional factors the development of competition in agricultural markets]. Aktualni problemy ekonomiky, 3(153), 15-22.

Lopatynskyj, Ju. M. (2006). Instytucionalizacija tranzytyvnoi ekonomiky [The institutionalization of transitive economy]. Nauchnye trudy DonNTU. Serija jekonomicheskaja, 103-1, 15-22.

Nort, D. (1997). Ynstytucyonalnyye yzmenenyja: ramka analyza [Institutional changes: framework of analysis]. Voprosy ekonomiky, 3, 6-17.

Palmer, T. D. (2014). Moralnist kapitalizmu. Te, pro shho vy ne pochujete vid vykladachiv [The morality of capitalism. What you will not hear from the teachers]. Kyiv: Osnovy.

Rodzhers Everett, M. (2009). Dyfuzija innovacij [The diffusion of innovations]. (V. Starka, Trans). Kyiv: Vyd. dim "Kyjevo-Mogyljanska akademija".

Sabluk, P. T. (2010). Rozvytok instytucij udoskonalennja mehanizmu reformuvannja agrarnogo sektoru ekonomiky [The development of institutions to improve the mechanism of reforming of agrarian sector of economy]. Ekonomika APK, 10, 3-11.

Shumpeter, J. Teorija ekonomichnogo rozvytku: Doslidzhennja prybutkiv, kapitalu, kredytu, vidsotka ta ekonomichnogo cyklu [The theory of economic development: a Study of profits, capital, credit, interest and economic cycle]. (V. Starka, Trans). Kyiv: Vydavnychyj dim "Kyjevo-Mogyljanska akademija".

Veber, M. (2016). Hozjajstvo i obshhestvo: ocherki ponimajushhej sociologii [Economy and society: essays on the understanding of sociology]. Jekonomicheskaja sociologija, 5(17), 13-28. 